\title{
Jim Crow Democracy: The U.S. South and Racialized Policy-Making in the Aftermath of World War II
}

\author{
Maarten Zwiers
}

HCM 7: 547-565

DOI: $10.18352 / \mathrm{hcm} .570$

\begin{abstract}
Segregationist politicians from the U.S. South played key roles in devising plans for the reconstruction of Germany, the Marshall Plan and the drafting of displaced persons legislation. This article discusses how their Jim Crow ideology calibrated the global and domestic order that emerged from the ashes of World War II. Southern advocates of this ideology dealt with national and foreign issues from a regional perspective, which was based on the protection of agricultural interests and a nascent military-industrial complex, but above all, on the defence of white supremacy. In general, they followed a lenient course toward Germany after the country's defeat in World War II, for various reasons. The shared experience of post-war reconstruction, containment of communism and feelings of kinship between the Germanic people and the Anglo-Saxons of the U.S. South were some of the motives why many white southerners did not endorse punitive measures against the former enemy. For them, an obvious connection existed between the local and the global, which strongly reverberated in the formation of U.S. foreign and domestic policy in the post-war world. The rebuilding of Germany and the fugitive question were shaped on the basis of a Jim Crow blueprint.
\end{abstract}

Keywords: anti-communism, Cold War, Marshall Plan, racialization, refugees, U.S. South 


\section{Introduction: the U.S. South in the World}

In December I933 manufacturers from the U.S. South founded the Southern States Industrial Council (SSIC). The initial goal of the organization was to protect southern business interests within the New Deal framework. After World War II, it became an advocate of a typical form of southern free enterprise, based on minimal federal regulations, limited government spending, anti-communism, strict immigration laws and a devotion to racial segregation. ${ }^{.}$These subjects often figured prominently in the Bulletin, the newsletter of the SSIC. The issue of I5 July I957 for instance contained excerpts from a speech by U.S. Senator Herman Talmadge of Georgia, who criticized 'the panicky and unstable' foreign policy of the United States as being too complacent to demands of the Soviet Union. Council president Martin Condon defended the McCarran-Walter Act, a very restrictive immigration bill passed by Congress in I952 over President Harry Truman's veto, while columnist Thurman Sensing denounced the Supreme Court as a Marxist outfit that had illegally declared segregation in public schools unconstitutional and limited congressional authority to investigate subversive activities. According to Sensing, the verdict to desegregate education was an 'uncalled-for, radical, communist-pleasing decision of the Supreme Court'. Condon similarly claimed communists were trying to 'emasculate [the McCarran-Walter Act] and to open the flood-gates to foreign immigration'. Anti-communism was the common denominator for the segregationist, nativist and capitalist sentiments that characterized the 'America First' agenda of the Southern States Industrial Council. ${ }^{2}$

The SSIC newsletter demonstrates how the context of the global Cold War determined southern ideas about national and international developments. During the last decades, such a global dimension has increasingly taken centre stage in scholarship on the U.S. South. ${ }^{3}$ Researchers have successfully applied the concept of the 'Global South' to the history of slavery, of antebellum southern nationalism (and secession) and of the civil rights movement. ${ }^{4}$ Although the historiography on the transnational aspects of the black freedom struggle is more extensive, the interconnections between southern segregation and white supremacy abroad have not gone unnoticed either. Foreign policy scholars such as Thomas Borstelmann, Gerald Horne and Andrew 
DeRoche have written important books about U.S. relations with southern Africa, where white minorities controlled countries such as South Africa and Rhodesia. Borstelmann's work The Cold War and the Color Line investigates how the U.S. government responded to demands for racial equality at home and abroad during the Cold War. 'The essential strategy of American Cold Warriors was to try to manage and control the efforts of racial reformers at home and abroad, thereby minimizing provocation to the forces of white supremacy and colonialism while encouraging gradual change', Borstelmann argued. In his book, he rightfully points out how students of U.S. foreign policy have generally neglected 'domestic realities', while historians of the civil rights era have often presented the movement as uniquely American, thus ignoring the battle against colonial regimes that was raging at the same time. ${ }^{5}$

In contrast with Borstelmann's emphasis on presidential administrations, historian Stephanie Rolph takes a more grassroots approach in her examination of Citizens' Council support for scientific racism and African apartheid regimes. The Citizens' Council was a white supremacist organization founded in the U.S. South after the Supreme Court had ruled segregated public education unconstitutional in 1954. Rolph intends to bring 'white fears of racial equality into better focus ... from this viewpoint, dismantling legal segregation and extending political equality could only result in tyranny and violence against whites everywhere'. Segregationists and supporters of white control more generally operated across regional and national borders within a 'global ecosystem of white supremacy', Rolph argued. ${ }^{6}$ She convincingly exposes the importance of white privilege in the contemporary conservative movement in the United States and the transnational outlook of the Citizens' Council. ${ }^{7}$ However, in her article Rolph primarily concentrates on alliances white supremacists from the U.S. forged with kindred spirits in Africa, which limits the truly global scope of segregationist ideology to specific cases on one continent.

White supremacist causes in Rhodesia and South Africa somewhat resembled the domestic defence of Jim Crow apartheid. Historian Stephen Berrey defined the system of Jim Crow as a racialized social structure whose objective was 'to solidify and extend white political and economic power'. It did not just preserve white supremacy through politics and law, but also functioned as a cultural system, in 'daily performances of race' ${ }^{8}$ Comparable systems existed in southern Africa, 
which explains why historians interested in the foreign dimensions of U.S. segregation devote so much attention to the African continent. But southern segregationists had a much broader range of global interests than just Africa. Politicians from the Jim Crow South for instance played important roles in drafting reconstruction proposals for Germany, the Marshall Plan and displaced persons legislation, all based on their racialized belief system. 'Dixie's congressmen furnished crucial leadership and support for confronting international Communism and implementing containment', historian Joseph Fry wrote about the South's substantial impact on U.S. conduct in the Cold War. Southern Democrats 'endorsed and managed congressional approval of the United Nations, the Truman Doctrine, the Marshall Plan, and NATO'. ${ }^{9}$ Post-war Europe occupied a prominent place in the foreign policy agenda of the white South. Racialized ideas about foreign aid, the Soviet communist threat and the refugee situation undergirded this agenda. Southern politicians wanted to safeguard Jim Crow democracy at home and simultaneously export its main tenets abroad.

\section{Racialized Policy-Making}

The following focuses on U.S. responses to developments in Europe in the direct aftermath of World War II. I argue that race was central to key decisions concerning Europe during this period and that southern lawmakers played an important role in drafting these decisions. This article thus complements the work done by scholars on U.S. race-based attitudes toward Africa during the Cold War, where the colour line figured prominently. Traditional explanations for U.S. aid to post-war Europe often combine humanitarian considerations, economic interests and containment of communism. For committed southern segregationists, something much more significant was at stake: the survival of Western civilization, which they defined as white. Racial concerns were therefore of crucial importance to them in the reconstruction of Germany, their support for the Marshall Plan and their involvement in the European refugee question. They successfully found allies outside the South to implement their anti-communist free enterprise agenda, which essentially served one goal: to make the world safe for Jim Crow democracy. 
In their work on racial formation, sociologists Michael Omi and Howard Winant use the concept of racialization to explain how meaning is attached to human physical features, in this case skin colour. 'Conscious or unconscious, deeply ingrained or reinvented, the making of race, the "othering" of social groups by means of the invocation of physical distinctions, is a key component of modern societies', they write. According to them, racialization was central to the organization of the modern world-system. Until this day, we are dealing with the racialized legacies of this history, which fundamentally revolved around conquest and exploitation. 'Racial categories, and the meanings attached to them, are often constructed from pre-existing conceptual or discursive elements that have crystallized through the genealogies of competing religious, scientific, and political ideologies and projects', Omi and Winant elucidate the historical dimension of racialization. ${ }^{\text {I }}$

With its long history of large-scale slavery and institutionalized segregation, extreme forms of racialization structured society in the U.S. South. Its white supremacist mindset nonetheless became a U.S. export product in the post-war era. First of all, as Joseph Fry already indicated, southern lawmakers occupied congressional positions of power in the fields of foreign policy and national security. In the second place, whiteness was a constituent element of the national self-image, which meant that diluted forms of southern racial extremism could easily blend with dominant forms of U.S. identity. Finally, racialization was also integral to processes of national self-definition and the creation of so-called collective 'cultural archives' in Europe. ${ }^{\text {II }}$ 'Especially since the imperial dawn, the ideas of race and nation have been deeply connected, mainly through concepts of peoplehood', Omi and Winant explain. ${ }^{12}$ In other words, Jim Crow democracy could effectively be channelled to other parts of the nation and other parts of the globe, especially through its association with anti-communism and free enterprise.

\section{German Reconstruction and the Marshall Plan}

On 26 May I945, eight U.S. senators of the Committee on Naval Affairs landed at Orly Airfield in Paris, France. After touring the D-Day beaches in Normandy and the Battle of the Bulge area in Luxembourg, the group travelled to Germany. Six of the eight senators were Democrats 
from the U.S. South: Harry Byrd of Virginia, Burnet Maybank of South Carolina, John McClellan of Arkansas, Tom Stewart of Tennessee, Richard Russell of Georgia and James Eastland of Mississippi. Many of them could readily identify with the destruction they saw in the defeated Third Reich. These men had grown up with the mythology of the Lost Cause, a rendition of history that presented the Confederate war effort as a noble struggle for independence against tyranny. Lost Cause apologists considered the post-Civil War period a tragic and chaotic era when former slaves and Yankee sympathizers ruled their destroyed homeland. With the Red Army standing at the gates of Western Europe, segregationists from the U.S. South believed that yet another battle for the survival of (what they called) white civilization was at hand. ${ }^{13}$

When they returned to the United States, these southern politicians were convinced they had to fight for a lenient reconstruction policy of Germany. The defence of whiteness, anti-communism and the revival of a European free market economy formed the core of their arguments. Capitalism and Jim Crow democracy thus merged in their vision of a post-war world. This vision was diametrically opposed to the plans of Henry Morgenthau, Franklin Roosevelt's Secretary of Finance. Morgenthau was the son of a Jewish real estate tycoon from New York City and became part of the Roosevelt administration in I933. In I944 he drafted a proposal about what should happen with the Third Reich after Nazi defeat, titled 'Suggested Post-Surrender Program for Germany'. Morgenthau's basic premise was that Germany should never again be capable of waging war. Its major industries should be dismantled and the country should be turned into a pastoral state. Roosevelt and Churchill initially favoured the so-called 'industrial disarmament' of Germany. ${ }^{14}$ When propaganda minister Joseph Goebbels heard about the plan, he used it in his efforts to rally the German population behind the 'Totaler Krieg'. According to Goebbels, 'the American Jew Morgenthau' wanted to turn Germany into a giant potato field. ${ }^{15}$

The idea to make Germany 'primarily agricultural and pastoral in character' met fierce opposition from southern segregationists. U.S. Representative Bill Colmer of Mississippi, the Democratic chairman of the Special Committee on Post-War Economic Policy and Planning, led a congressional delegation on a two-month fact-finding tour through Europe in the fall of I945. The delegates also interviewed Soviet leader Joseph Stalin during their trip. In November, Colmer issued a scathing condemnation of U.S. policy in Germany: he believed an economic 
recovery program should be established as soon as possible to combat the starvation and economic distress that was rampant in the country. ${ }^{16}$

Other southern politicians fell in line with the conclusions of the Colmer report. Senator Eastland called upon the administration to stop the 'policy of vindictive hatred' that caused 'grave hardship, starvation, and human suffering'. Germany was the 'industrial heart of Europe' and 'the neutralizing agent between the Oriental hordes [i.e. Russian communists] and a western civilization 2000 years old'. The establishment of a strong German economy was necessary because there could 'be no sound, permanent peacetime prosperity in the United States until the economy of Europe is put upon a sound permanent basis'. Eastland also believed communist rule was 'the first time in the Christian era that the doctrine of slavery has been adopted as applied to the white race... We are abandoning the principles of Christian civilization, for not since the days of Nero have Christians been treated so cruelly' by the Soviet Union, a 'predatory, aggressor nation' in the words of Eastland. ${ }^{17}$ In the end, under growing pressure from the South and other parts of the country, the U.S. government decided to abandon the Morgenthau Plan. ${ }^{18}$

As an outspoken anti-communist advocate of white supremacy, Eastland racialized containment of the Soviet threat. He described Germany as the defender of Western civilization, Christianity and a free market economy, while Russian Marxism was an oriental ideology aimed at aggressive expansion and the enslavement of white people. By calling communism oriental, Eastland automatically defined it as non-white and triggered time-honoured 'yellow peril tropes' stored in the U.S. cultural archive. Such rhetorical strategies became an inherent part of post-war American conservatism. ${ }^{19}$ At the same time, Eastland adapted racialized ideas about presumed communist affinities in the African American civil rights movement and applied them in the debate on the reconstruction of Germany. ${ }^{20}$ In doing so, he made the defence of white supremacy in the U.S. South part of a global fight for the basic tenets of Western civilization. In this fight, people of colour were framed as having a stronger proclivity for Marxism, while whites stood for democracy and free enterprise. Eastland received wide praise for his Germany speech from all parts of the country. 'In condemning the un-American and unchristian conditions imposed upon the German people you have the wholehearted support of millions of your fellow citizens', a resident of Pittsburg, Pennsylvania wrote the Mississippi senator. $^{21}$ 
The reconstruction of Germany became part of a much larger attempt to rejuvenate the post-war economy of war-ravaged Europe. The South's support for the implementation of this European Recovery Program (ERP, better known as the Marshall Plan) was again crucial. In the spring of 1947, Dean Acheson, Truman's undersecretary of state, travelled to Greenville, a bustling city located in the heart of the Mississippi Delta. Acheson's hosts organized a traditional southern dinner party for their distinguished guest that night, complete with mint juleps. The next morning, exactly two years after VE-Day, Acheson travelled north through the cotton fields, to the small town of Cleveland, where the Delta Council held its annual meeting. The Council was an organization of planters and small entrepreneurs who lived and worked in the fertile Black Belt along the Mississippi River, an area that stretched from Memphis all the way down to Vicksburg. 'Most of them have a world outlook and a modern attitude toward agriculture', Acheson's assistant Joseph Jones described the Council members. 'Cotton remains the main crop, and cotton requires world markets, hence the traditional internationalism of the delta' ${ }^{22}$

It was a typical spring day in the Deep South: hot and humid. A large crowd of farmers awaited Acheson in the gymnasium of what is now known as Delta State University. Since the beginning of April I947, Jones had been working on a speech for his boss about America's responsibility in the reconstruction of Europe. Besides mentioning the leadership of the United States in the global fight for democracy, Acheson instructed Jones to emphasize economic self-interest and national security as well. The discussion of a new role for Germany in the European recovery plan formed a central element of the speech. U.S. officials no longer wanted to treat the Germans as enemies who should suffer for past sins, but as possible allies in the emerging Cold War. ${ }^{23}$ 'It is clear, therefore, that in order to promote political stability, in order to preserve democratic institutions in the world, in order to create economic bases for peace, and in order to protect our domestic economy', Jones explained, 'it is clear that for all these reasons we must be prepared in the years to come to extend financial and economic assistance to the world on a scale which we have not hitherto considered' ${ }^{24}$

The audience listened attentively as Acheson stressed the urgency of rebuilding Europe. According to the undersecretary, the United States not only had a moral obligation to enact such a program; it was also essential to contain the Soviet threat and secure foreign markets. 'It is 
necessary if we are to preserve our own freedoms and our own democratic institutions', he said. 'It is necessary for our national security. And it is our duty and our privilege as human beings'. ${ }^{25}$ The cotton planters greeted Acheson's call for aid to Europe with applause. More than a third of cotton exports went to Western Europe. For farmers in the Delta, it was not difficult to see the link between European recovery, anti-communism and their own economic well-being. Less than a month later, Secretary of State George Marshall officially announced the European Recovery Program in a speech at Harvard University. But Acheson had launched the trial balloon for the plan, in the heartland of the Jim Crow South, where just a few years later the first Citizens' Councils emerged. ${ }^{26}$

The administration's choice for Cleveland, Mississippi, as the site to introduce the ERP underscored the central position of agricultural exports in the program and it revealed the importance of southern support for the enactment of the project. Acheson's trip to the Deep South was imperative, because considerable opposition to the Marshall Plan still existed in the region. ${ }^{27}$ Segments of the southern electorate for instance did not understand why a former enemy should receive U.S. dollars to rebuild its economy, just two years after the war. Cullen Curlee, who ran James Eastland's Mississippi office, wrote the senator that these voters did 'not realize should we not contribute something to the upbuilding of the foreign countries it would result in a chaotic condition and the communists and Russians would be sure to take advantage of the situation blaming it all on us'. Curlee also mentioned how cotton exports from the South would suffer if Europe did not receive U.S. aid to revive its markets. ${ }^{28}$ Such considerations, which revolved around the interplay between race, anti-communism and the creation of demand abroad for southern farm products, were enough reason for many legislators from the South to support the ERP. ${ }^{29}$ With the critical backing of Jim Crow Democrats secured, Congress passed the Marshall Plan in mid-I948.

\section{Bloodstreams and Citizenship in the Displaced Persons Debate}

In the eyes of Jim Crow apologists, only a strong Germany could form a white, Christian, capitalist bulwark against the expansion of oriental, atheistic communism. These ideas were subsequently transferred to the 
European level, with the enactment of the ERP. Nothing less than the survival of western civilization was at stake. Such a worldview also defined the southern position in the displaced persons debate that took place in 1949 and I950. In I946, Harry Truman had already requested Congress to rewrite legislation for admitting displaced persons into the country. The president could finally sign a new bill two years later, but he was not very enthusiastic about it. The president had hoped Congress would design a lenient law with low entry requirements, but the powerful conservative caucus on Capitol Hill had other thoughts. These politicians were not very eager to open the borders for victims of World War II. The result was a very restrictive bill that set firm quotas on the admittance of displaced persons into the United States. Democratic Senator Pat McCarran, a reactionary rancher from Nevada, had senior status on the Judiciary Committee, which decides on immigration matters. McCarran in fact wanted to ship most refugees to Alaska and keep the American mainland free of displaced persons. After the Democratic victory in the I 948 elections, Truman expected that his party would draft a more liberal displaced persons (DP) law. Democrats were again in control of Congress, but not all of them fell in line with the president's wishes. Chairman McCarran was one of them..$^{30}$

New York Representative Emanuel Celler and Senator J. Howard McGrath of Rhode Island took up the challenge to steer Truman's plans through the House and Senate. The biggest obstacle for these two Democrats from the North was a subcommittee composed by McCarran that had to examine proposals for a revised DP law. Republican William Jenner of Indiana and Jim Crow Democrat James Eastland were members of this committee and they vehemently opposed liberal amendments to the act. After almost four months of hearings, Pat McCarran announced he had to go to Europe to personally examine the refugee situation in the region. His trip was a stalling strategy to keep the bill in committee. McCarran relied on senatorial courtesy that the full Senate would not debate new legislation when the chairman was away on a fact-finding mission..$^{31}$

The Judiciary Committee finally submitted a DP bill on 24 January I950 for consideration by the Senate. Parts of the original proposal had made it through the subcommittee hearings, but Congressman Celler was not very content with the alterations to his bill and called it a fraud. The main reason for Celler's objections were the subcommittee's attempts to broaden the definition of displaced persons. The 
DP bill was initially intended to offer relief for victims of the Nazi regime, but McCarran's amendments allowed the entry of refugees who were persecuted or feared persecution between I September I939 and I January I949. The subcommittee also decided to retain specific quota arrangements from the original displaced persons act of I948. These quotas favoured refugees coming from Europe and who were involved in agriculture. Especially German transplants in Eastern Europe benefited from such provisions. These so-called Volksdeutsche were ethnic Germans who were born and living outside Germany. Many of them had fled their homeland after the post-war communist takeover. Jewish people became the victim of the subcommittee version of the Celler bill, because the preferential treatment of Germanic refugees decreased the number of Jewish fugitives eligible for entry into the United States..$^{32}$

Senator Eastland strongly supported the positive discrimination of Germans from Soviet-occupied zones who wanted to come to the States. When the Senate discussed the displaced persons issue in October I949, he stated that no single 'group of people in the entire history of the world ever suffered more than they did' ${ }^{33} \mathrm{~A}$ few months later, Eastland proudly claimed Germans resembled white southerners, who were 'of as pure Anglo-Saxon blood as can be found in the United States'. Eastland thought that one 'of the greatest crimes in all history was the uprooting [of Germans] from their homes, where their people had lived for centuries, of men, women, and children, whose only offense was that through their veins flowed Germanic blood and that a thousand years ago their ancestors had been of German stock' ${ }^{34}$ Herbert Lehman, a liberal Democratic senator from New York, expressed strong criticism of Eastland's statements. According to Lehman, McCarran and his allies on the Judiciary Committee attempted 'to change the entire nature of the [DP] program from one of relief for displaced persons to one of relief of German expellees' ${ }^{35}$

Opponents of a more tolerant displaced persons policy feared the influx of communist spies from Eastern Europe and the Soviet Union. Richard Russell of Georgia, a Democrat and leader of the Southern Caucus in the U.S. Senate, had in fact received information about refugees forging passports, college degrees, birth certificates and even family Bibles. 'It was my informant's opinion that a great many of them were Russian agents and that they had been deliberately planted by the Russian Government in those positions [displaced persons camps], so 
that they could go into the democracies who were accepting displaced persons, and could cause trouble there, through subversive activities', Russell warned. ${ }^{36}$ Segregationists often linked ethnicity with the propensity for communist sympathies and the ability (or rather inability) to understand American political traditions. Jim Crow spokesmen claimed that minorities such as African Americans but also Jews were more open to Marxist ideology. Democratic Congressman John Rankin from Mississippi voiced this viewpoint in extreme language. He was once asked to bring a 'Jew Communist' to his home state, but Rankin declined, saying he did not want to pollute 'the magnolia-scented sweetness of pure Mississippi with a stench so foul that buzzards held their noses while flying over the Jew Communist meeting places' ${ }^{37}$

Amy Kaplan has demonstrated how in the U.S. 'domestic metaphors of national identity are intimately intertwined with renderings of the foreign and the alien'. ${ }^{38} \mathrm{Jim}$ Crow Democrats followed a similar pattern, preferring the immigration of groups with a kindred ethnic background as the Anglo-Saxons of the South. Senator Eastland for instance wanted to open U.S. borders for Germanic farmers, who he considered close to the white people of Mississippi. 'Do Senators know that under this bill a person who took up arms against Russia when the Russian Armies invaded his country, and who fought to protect his country, is ineligible to come into the United States as a displaced person under the Celler bill which we are asked to pass', Eastland asked his colleagues. He then declared that the liberal version of the DP bill was 'founded in discrimination. It stinks of discrimination against loyal, patriotic groups who should be permitted to come here, and who would be an asset to our country'. ${ }^{39}$ Parts of the Volksdeutsche population had worked together with the Nazi regime. Eastland thought this stigma of collaboration negatively affected the entire community after the war. For him, Germanic fugitives trying to escape communist oppression did not form a threat to the American Way of Life, which became very obvious when he compared them with refugees from Eastern and Central Europe of different ethnic stock. Senator Eastland was open to immigration, but the newcomers should have an ethnicity compatible with the WASP heritage of the South and the United States. Moreover, they should have clearly displayed their anti-communist sentiments. As tensions between Soviet Russia and the United States increased, Eastland was not the only American who voiced such opinions. 
The ideas expressed by Jim Crow politicians on the refugee situation fit into a wider regional worldview that had the Cold War as its framework. The fear that alien forces wanted to destroy the Southern Way of Life was central to this system of thought. Moreover, high officials in the Truman administration had similar views. George Kennan for instance stated that the appeal of communism "was relatively strong to maladjusted groups - Jews, Negroes, immigrants - all those who feel handicapped in the framework of a national society'. ${ }^{40}$ U.S. citizens outside the South were also concerned about the influx of Jewish refugees and their presumed communist sympathies. A woman from New York wrote: "The word "refugee" is synonymous with Jew, and the latter is synonymous with Red!"41 Others saw Jim Crow Democrats as custodians of American political traditions. A resident of Long Beach, California thought 'that if this country can be saved, it will have to be done by southerners, as they have the most purely Anglo-Saxon view of government'. ${ }^{2}$

White southerners were therefore not the only ones who connected ethnicity with subversive behaviour, but their representatives in Congress had the political power to influence legislation about refugees and the economic reconstruction of Europe. On the basis of the system of seniority, many of them chaired congressional committees that directly dealt with Cold War issues, such as the Foreign Relations Committee and the Armed Services Committee..$^{43}$ During the displaced persons debate, reactionary Republicans like William Jenner of Indiana banded together with conservative Democrats from the West and South to stand in the way of a liberal DP bill. In later years, these two regions, the West and the South, would of course form the bedrock of a revamped Republican Party.

In I950, this conservative coalition was unable to prevent the passage of a fairly liberal displaced persons law. Retaliation followed the same year however, when McCarran introduced his Internal Security Act. The law provided for the establishment of a subversive activities control board, which registered members of communist and front organizations, denied passports and government positions to Marxist sympathizers, intensified espionage legislation and made the extradition of subversive aliens easier. Liberals opposed the bill, but it still passed Congress on 20 September. President Truman did not want to sign it. He thought the McCarran Act laid the cornerstone for the 
creation of a totalitarian state, with little regard for basic civil liberties, either of foreigners or U.S citizens. Truman therefore sent the bill back to Capitol Hill. The House and Senate were not impressed by Truman's veto, however. Congress overrode it, and the Internal Security Act of I950 became law on 23 September. It became a powerful weapon for congressional guardians of Jim Crow, who would use the act to persecute all agents of progressive change, including civil rights workers and labour activists. ${ }^{44}$

\section{Conclusion: Jim Crow Goes Global}

Jim Crow Democrats based their Cold War policy decisions on a white supremacist worldview. Their support for the reconstruction of Germany, the Marshall Plan and a strict displaced persons law was connected to the defence of the existing race and class system in the U.S. South. The danger of communist expansion and infiltration and the post-war process of decolonization posed a menace to traditional power structures, both at home and abroad. The southern economy relied on free markets, military spending and cheap labour. Racial and class identity determined social status in the American South. Issues of race and labour were therefore intimately linked in the southern states, which made politicians from the area very apprehensive about the advancement of human rights, not only by the U.S. government, but also through the United Nations. Because human rights advocates promoted political and socioeconomic justice, white southerners considered their message a direct danger to established race and class relations in the region.

World War II not only transformed the international system of politics, but also caused massive change within the United States, particularly in the South. This process had already started with the New Deal, but accelerated during the war. The mechanization of agriculture, (military) industrialization in the southern states and the rise of the civil rights movement strained class and race relations in the region. African American veterans who returned home after defeating fascism formed the vanguard in the battle for racial equality. They pointed out the paradox of American foreign policy: while the United States claimed to be fighting for freedom and democracy abroad, a system of institutionalized segregation was still firmly in place in a large part of the country. 
Segregationists often conflated Americanism with anti-communism to present their Jim Crow agenda as the epitome of U.S. constitutionalism. As such, opponents of the southern status quo - civil rights and labour activists at home, left-wing freedom fighters abroad - automatically became dangerous Soviet sympathizers. The domestic defence of segregation also translated into strong southern backing for anti-communist strongmen after World War II, like Francisco Franco of Spain and Rafael Trujillo of the Dominican Republic. ${ }^{45}$ In I 958 for instance, James Eastland teamed up with his Republican colleague William Jenner to personally address Trujillo. 'Thank God for your country and for your leadership for freedom, for capitalism, and for free enterprise', Eastland told the ruthless dictator. ${ }^{46}$ The Mississippi senator was not the only Jim Crow Democrat who travelled to the Dominican Republic and wrote about it in lofty terms. U.S. Senator Olin Johnston of South Carolina visited the country in 1957 and contrasted the situation there with political instability in Haiti. 'My recent travels through Haiti and the Dominican Republic provided an excellent basis for comparison between two governments sharing the same island', he observed, 'one torn by communistic-inspired instability and the other stable, firm, and well organized' ${ }^{47}$ In his travel report, Johnston utilized longstanding racialized tropes about Haiti. The origins of these tropes can be traced back to the antebellum era, when Haiti gained independence through an uprising of its enslaved population and slavery in the southern United States began to expand. $4^{8}$

Besides anti-communism, Eastland and other segregationists from the United States thus could relate to Trujillo on other levels too. He forcefully ran the country as his own (sugar) plantation and created a colour line between Dominicans and darker-skinned Haitians that must have appeared familiar to Jim Crow apologists. 'Trujillo as farmer, worker, and industrialist promised to create a society with no castes... no blackness - one of only Dominicans united against Haitians', historian Lauren Derby wrote. 'If blackness in this context was a metaphor for social inequality, the Era of Trujillo promised to make whiteness available to all Dominicans by incorporating them in the modern nation' ${ }^{49}$ Continued U.S. support for dictatorial regimes during the early Cold War reflected southern ideas about national security and a world order safe for American interests. ${ }^{50}$

The notion of freedom in the Jim Crow South was shaped by the fear of national and international revolutionary change, instigated by 
communist sympathizers, independence fighters and human rights activists. The vast national and international transformations that occurred after World War II filled advocates of Jim Crow with anxiety. The communist advance inside and outside the United States, for them exemplified by the civil rights movement on the one hand and the Red Army on the other, had to be stopped. When viewed from this perspective, the Marshall Plan became an instrument to protect the white South's interests, not only in the field of economics, but also in the field of race. Immediately after the Nazis were defeated, Germany became part of a global ecosystem of white supremacy created by proponents of Jim Crow democracy who wanted to protect their racialized vision of Americanism and spread it across the world. At the same time, this racialized vision defined white southern views during the displaced persons debate in the United States.

\section{Notes}

I Katherine Rye Jewell, Dollars for Dixie: Business and the Transformation of Conservatism in the Twentieth Century (Cambridge, 20I7) 5-7.

2 SSIC Bulletin, I5 July I957, in Right Wing Collection, reel I07, Roosevelt Institute for American Studies, Middelburg, the Netherlands (hereafter referred to as RIAS).

3 For a comprehensive overview of this work, see Martyn Bone, Where the New World Is: Literature about the U.S. South at Global Scales (Athens, 20I8) I-27.

4 With regard to the civil rights struggle, the following books have become standard works: Carol Anderson, Eyes Off the Prize: The United Nations and the African American Struggle for Human Rights, 1944-1955 (Cambridge, 2003), Mary L. Dudziak, Cold War Civil Rights: Race and the Image of American Democracy (Princeton, 2000), Brenda Gayle Plummer, Rising Wind: Black Americans and U.S. Foreign Affairs, I935-1960 (Chapel Hill, I996), Penny M. Von Eschen, Race Against Empire: Black Americans and Anticolonialism, 1937-1957 (Ithaca, 1997) and Robert Trent Vinson, The Americans Are Coming!: Dreams of African American Liberation in Segregationist South Africa (Athens, 2012).

5 Thomas Borstelmann, The Cold War and the Color Line: American Race Relations in the Global Arena (Cambridge, 200I) 2, 6-7. 
6 Stephanie Rolph, 'The Citizens' Council and Africa: White Supremacy in Global Perspective', Journal of Southern History 82:3 (2016) 6I7-50, at 6I8. https://doi.org/I0.I353/soh.20I6.oI78.

7 See also Rolph's new book Resisting Equality: The Citizens' Council, I954-I989 (Baton Rouge, 2018).

8 Stephen A. Berry, The Jim Crow Routine: Everyday Performances of Race, Civil Rights, and Segregation in Mississippi (Chapel Hill, 2015) 2-3. See also Jennifer Ritterhouse, Growing Up Jim Crow: How Black and White Southern Children Learned Race (Chapel Hill, 2006) 8-9. Michelle Alexander researches the longevity of Jim Crow practices in The New Jim Crow: Mass Incarceration in the Age of Colorblindness (New York, 20I2).

9 Joseph A. Fry, Dixie Looks Abroad: The South and U.S. Foreign Relations, I789-I973 (Baton Rouge, 2002) 227, 260.

Io Michael Omi and Howard Winant, Racial Formation in the United States (3rd ed., New York, 20 I5) I I I.

I I See for instance Gloria Wekker, White Innocence: Paradoxes of Colonialism and Race (Durham, 2016) I-5, I 5-2 I, 25.

I 2 Omi and Winant, Racial Formation in the United States, 78. Emphasis in original.

I3 Lee Annis Jr., Big Jim Eastland: The Godfather of Mississippi (Jackson, 20I6) $7 \mathrm{I}-2$.

I4 Chris Myers Asch, 'Revisiting Reconstruction: James O. Eastland, the FEPC, and the Struggle to Rebuild Germany, I945-1946', Journal of Mississippi History 67: I (2005) I-28, at I6-7.

I 5 Jeffrey K. Olick, In the House of the Hangman: The Agonies of German Defeat, I943-I949 (Chicago, 2005) 3I.

I6 Asch, 'Revisiting Reconstruction', I7-8.

I7 Ibid., I 8-9.

I 8 Ibid., 20.

I9 Stephen Del Visco, 'Yellow Peril, Red Scare: Race and Communism in National Review', Ethnic and Racial Studies 42:4 (2017) 626-44, at 639. https://doi.org/I0.I080/OI4I9870.20 I 7.I 409900.

20 For the domestic use of anti-communism as a segregationist weapon against the civil rights movement, see for instance George Lewis, The White South and the Red Menace: Segregationists, Anticommunism, and Massive Resistance, I945-I965 (Gainesville, 2004); Jeff Woods, Black Struggle, Red Scare: Segregation and Anticommunism in the South, I948I968 (Baton Rouge, 2004). 
2 I John Canetta to James O. Eastland, 4 December I945, in File Series 3, Subseries I, Folder: Eastland Address - Germany I945, in James O. Eastland Collection, Archives and Special Collections, J.D. Williams Library, University of Mississippi (hereafter referred to as JOE Collection).

22 Joseph M. Jones, The Fifteen Weeks (February 2 I - June 5, I947) (New York, I955) 26.

23 Robert L. Beisner, Dean Acheson: A Life in the Cold War (Oxford, 2006) 7I.

24 Joseph M. Jones to Dean Acheson, with attached draft outline notes for speech, 23 April I947, in J.M. Jones Papers, Subject File, Dean Acheson's speech before Delta Council, Harry Truman Presidential Library website, https://bit.ly/3 IruVdy, accessed I I June 20 I9.

25 Speech by Dean Acheson, 'The Requirements of Reconstruction', The Department of State Bulletin I6:4 I ( I947), Harry Truman Presidential Library website, https://bit.ly/2R8RTRM, accessed I I June 2019.

26 Alfred O. Hero Jr., The Southerner and World Affairs (Baton Rouge, I965) 200; James C. Cobb, The Most Southern Place on Earth: The Mississippi Delta and the Roots of Regional Identity (New York, I994) 2 I3-7.

27 The SSIC for instance did not support the Marshall Plan, because it opposed all forms of federal handouts. See SSIC Bulletin, I October I954; SSIC Bulletin, I5 March I956, both in Right Wing Collection, reel I07, RIAS.

28 Cullen B. Curlee to James O. Eastland, Io November I947, in File Series I, Subseries 2 I, Folder: I-5 (I947), in JOE Collection.

29 Fry, Dixie Looks Abroad, 229-30.

30 Maarten Zwiers, Senator James Eastland: Mississippi's Jim Crow Democrat (Baton Rouge, 20I5) 78.

3I Ibid., 78-9.

32 Leonard Dinnerstein, America and the Survivors of the Holocaust (New York, I982) I 85, 242-3.

33 Congressional Record 95 ( 5 October I949) I 4698.

34 Congressional Record 95 (3 March I950) 2736-7.

35 Dinnerstein, America and the Survivors of the Holocaust, 243.

36 Congressional Record 94 (2 June I948) 6864.

37 Kenneth W. Vickers, 'John Rankin: Democrat and Demagogue', unpublished MA thesis, Mississippi State University, I993, 95.

38 Amy Kaplan, The Anarchy of Empire in the Making of U.S. Culture (Cambridge, 2002) 4.

39 Congressional Record 95 (I5 October I949) I 4698.

40 Dinnerstein, America and the Survivors of the Holocaust, 236. 
4I Leonard Dinnerstein, 'Anti-Semitism Exposed and Attacked, I945-I950', Jewish History 6I: I ( I98 I) I34-I49, at I40.

42 D.A. Linthicum to James O. Eastland, 8 March I946, in File Series 3, Subseries I, Folder: Civil Rights I946 (2 of 2), in JOE Collection.

43 Robert A. Caro, The Years of Lyndon Johnson: Master of the Senate (New York, 2002) 96.

44 Zwiers, Senator James Eastland, 83.

45 F. Edward Hébert to Omer F. Kuebel, 24 August I95 I, in Box 698, Folder 3, in F. Edward Hébert Papers, Manuscripts Collection 650, Louisiana Research Collection, Howard-Tilton Memorial Library, Tulane University, New Orleans, LA 70 i i 8.

46 'Jenner, Eastland Pay Tribute to Trujillo's Anti-Red Politics', The Daily Illini, I2 September I958, I I.

47 Olin D. Johnston, Communist Problems in Latin America (Washington, I957) 3 .

48 Matthew Pratt Guterl, American Mediterranean: Southern Slaveholders in the Age of Emancipation (Cambridge, 2008) 38-43.

49 Lauren Derby, The Dictator's Seduction: Politics and the Popular Imagination in the Era of Trujillo (Durham, 2009) 24.

50 The South has impacted U.S. international politics since the founding of the nation. Matthew Karp, This Vast Southern Empire: Slaveholders at the Helm of American Foreign Policy (Cambridge, 20I6) explores how planters from the South determined American foreign policy during the nineteenth century.

\section{About the Author}

Maarten Zwiers is an assistant professor in Contemporary History and American Studies at the University of Groningen, the Netherlands. He specializes in the history and culture of the U.S. South, rural studies and the history of political culture. He is the author of Senator James Eastland: Mississippi's Jim Crow Democrat (Louisiana State University Press, 20I5). He has published in Southern Cultures and the Southern Quarterly and contributed to the New Encyclopedia of Southern Culture and the Mississippi Encyclopedia. He is currently working on two projects, one about segregation and anti-communism in the Cold War Caribbean, the other explores transnational rural radicalism.E-mail: m.zwiers@rug.nl 